\title{
Fennel Affects Ovarian Cell Proliferation, Apoptosis, and Response to Ghrelin
}

\author{
Alexander V. SIROTKIN ${ }^{1,2}$, Richard ALEXA ${ }^{1}$, Saleh ALWASEL ${ }^{3}$, \\ Abdel Halim HARRATH ${ }^{3,4}$ \\ ${ }^{1}$ Constantine the Philosopher University, Nitra, Slovakia, ${ }^{2}$ Research Institute of Animal Production, \\ National Agricultural and Food Center, Lužianky, Slovakia, ${ }^{3}$ King Saud University, College of \\ Science, Zoology Department, Riyadh, Saud Arabia, ${ }^{4}$ University of Tunis El Manar, Higher \\ Institute of Applied Biological Sciences of Tunis, Tunis, Tunisia
}

Received July 21, 2020

Accepted January 7, 2021

\section{Summary}

The objective of this study was to examine the direct effects of the medicinal plant fennel (Foeniculum vulgare Mill.) on basic functions of ovarian cells, including proliferation, apoptosis, and response to the physiological hormonal stimulator, ghrelin. In the first series of experiments, porcine ovarian granulosa cells were cultured with $(1,10,100 \mu \mathrm{g} / \mathrm{ml})$ or without fennel extract. In the second series of experiments, cells were cultured with $(1,10$, $100 \mathrm{ng} / \mathrm{ml}$ ) or without ghrelin, alone or in combination with fennel extract $(10 \mu \mathrm{g} / \mathrm{ml})$. Expression of the proliferation marker, PCNA, and the apoptosis marker, bax, were analyzed via quantitative immunocytochemical methods. Fennel stimulated the accumulation of the proliferation marker, and suppressed the expression of the apoptosis marker. Ghrelin alone promoted proliferation and apoptosis of ovarian cells. The presence of fennel inhibited these ghrelin effects. These observations provide the first demonstration of (1) effects of fennel on farm animal reproduction, (2) direct effects of fennel on ovarian cells, (3) the ability of fennel to promote ovarian cell proliferation, to inhibit ovarian cell apoptosis, and to enhance the ovarian cell proliferation:apoptosis ratio. Furthermore, our results (4) confirm the involvement of ghrelin in the control of ovarian cell apoptosis and proliferation, and (5) demonstrate the ability of fennel to affect not only ovarian cell proliferation and apoptosis, but also to suppress the responses of ovarian cells to the upstream hormonal regulator ghrelin. Our results indicate the potential applicability of fennel as a bio-stimulator of farm animal reproduction.

\section{Key words}

Fennel (Foeniculum vulgare Mill.) • Ovary - Proliferation • Apoptosis • Ghrelin

\section{Corresponding author}

Abdel Halim Harrath, P.O. Box 2455, Department of Zoology, College of Science, King Saud University, 11451 Riyadh, Saudi Arabia. E-mail: hharrath@ksu.edu.sa

\section{Introduction}

The study and application of natural/plant substances have become a popular alternative to regular medicines, hormones, and antibiotics in human and veterinary medicine and animal production. One plant used extensively in Oriental medicine is fennel (Foeniculum vulgare Mill.). Fennel contains numerous biological active substances, and has antioxidant, cytotoxic, anti-inflammatory, anti-microbial, bronchodilatory, estrogenic, diuretic, lithontripic, galactogogue, emmenagogue, antithrombotic, hypotensive, gastroprotective, hepatoprotective, memory enhancing, and anti-mutagenic activities. Due to these activities, fennel is used as a functional food and treatment for more than 43 disorders (Rahimi and Ardekani 2013, Badgujar et al. 2014, Sadati et al. 2016). There is already some evidence for the utility of fennel in animal production. Fennel can be used to reduce methane production by ruminant gastric microflora (Patra et al. 2010, Abdalla et al. 2012), to improve feed conversion and growth in calves (Saeedi et al. 2017), to increase food conversion and performance in quails (Cabuk et al. 2014) and to prevent coccidiosis in chicken (Dragan et al. 2014). 
There are indications that fennel phytoestrogens can influence female reproductive processes. Fennel can promote menstruation and prevent the signs of menopause in women (Albert-Puleo 1980, Badgujar et al. 2014, Cirmanova et al. 2017). Fennel can also increase ovulation/egg laying rate in quails (Cabuk et al. 2014), promote ovarian growth and follicle development in mice (Khazaei et al. 2011, Hassanpour et al. 2017) and improve fertility in rats (Abdel-Wahab et al. 2017). Moreover, fennel can prevent the ovarian response to the toxic effects of cyclophosphamide in mice (Hassanpour et al. 2017) and cadmium in rats (Abdel-Wahab et al. 2017). Nevertheless, the effects of fennel on farm animal reproduction, as well as the mechanisms of fennel action on reproductive processes, have not been previously studied. It remains unknown whether fennel molecules affect ovarian cells directly, or via upstream central (hypothalamo-hypophysial) regulators. Furthermore, ovarian follicullogenesis and fertility, which could be affected by fennel, are determined by the equilibrium between two antagonistic processes - ovarian cell proliferation and apoptosis, as well as the response of these processes to upstream hormonal regulators. The effects of fennel on these processes have not been previously studied.

The objective of this study was to examine the direct effects of fennel on the basic functions of ovarian cells, including proliferation, apoptosis, as well as their responses to the physiological hormonal stimulator, ghrelin (Sirotkin and Meszarosova 2010, Sirotkin et al. 2011, Rak-Mardyla 2013, Sirotkin and Harrath 2014). For this purpose, we analyzed proliferation and apoptosis of porcine ovarian granulosa cells cultured with or without fennel extract, with or without ghrelin, and with a combination of fennel extract and ghrelin.

\section{Materials and Methods}

\section{Isolation and culture of granulosa cells}

Granulosa cells were isolated from the ovaries of non-cycling pre-pubertal gilts aged approximately $180 \mathrm{~d}$, that were slaughtered at a local abattoir. The ovaries were processed, and granulosa cells were isolated and collected as previously described (Sirotkin and Meszarosova 2010, Sirotkin et al. 2011) in 16-well chamber slides (Nunc Inc., International, Naperville, USA, $200 \mu \mathrm{l} /$ well). After creating cell monolayers, cells were cultured either without fennel extract (controls), or with $90 \%$ extract of fennel (Changsha Sunfull Bio-tech. Co, Hunan China) at concentrations of 1,10 , and $100 \mu \mathrm{g} / \mathrm{ml}$. Other cells were cultured either without (control) or with biological-grade human ghrelin (Sigma-Aldrich Inc., St. Louis, MO, USA) at concentrations of 1,10 , and $100 \mathrm{ng} / \mathrm{ml}$, alone. A third group of cells were cultured with ghrelin (1, 10, and $100 \mathrm{ng} / \mathrm{ml}$ ), in combination with $1 \mu \mathrm{g} / \mathrm{ml}$ extract of fennel. The molecules were dissolved in the culture medium immediately prior to their addition to cells. The cells in the control treatments were cultured in the absence of both fennel and ghrelin, while the blank control consisted of the cell-free medium. The cells remaining at the bottom of the wells were rinsed with icecold PBS ( $\mathrm{pH} 7.5$ ), fixed in paraformaldehyde (4\% in PBS, pH 7.2-7.4) for $60 \mathrm{~min}$, and kept at $4{ }^{\circ} \mathrm{C}$ in preparation for immunocytochemical analysis. The number and viability of the cells were determined using Trypan blue staining and a hemocytometer. Cell viability ranged between 70 and $80 \%$, and no statistically significant differences were observed in these indices between the control and experimental groups.

\section{Quantitative immunocytochemistry}

Granulosa cells were processed as previously described (Sirotkin and Meszarosova 2010, Sirotkin et al. 2011), and incubated in the presence of primary monoclonal antibodies, at dilutions of 1:500 in PBS, against PCNA (marker of proliferation;(Shiomi and Nishitani 2017), and bax (marker of cytoplasmic apoptosis; (Pena-Blanco and Garcia-Saez 2018) (both from Santa Cruz Biotechnology, Inc., Santa Cruz, USA). Thereafter, cells were incubated with secondary swine antibody against mouse IgG, labeled with horseradish peroxidase (Servac, Prague, Czech Republic, dilution $1: 1000)$ or porcine secondary antibody labeled with fluorescein isothiocyanate (FITC, Sevac, dilution 1: 500), for $1 \mathrm{hr}$. Cells labelled with FITC were mounted into VECTASHIELD Antifade Mounting Medium with 4',6diamidino-2-phenylindole (DAPI), a selective stain for cell nuclear DNA (Vector Laboratories, Burlingame, CA, USA). DAPI and the FITC-labeled secondary antibody were detected by fluorescence microscopy. Cells labelled with horseradish peroxidase were stained with 3,3'diaminobenzidine (DAB) substrate (Roche Diagnostics GmbH, Manheim, Germany), mounted into glycergel histologic mounting medium (DAKO Denmark A/S, Glostrup, Denmark), and then visualized under a light microscope. The number of stained cells and the location of intracellular molecules were determined based on the brown coloration of $\mathrm{DAB}$ peroxidase or the green 
fluorescence emitted by the FITC label, and the ratio of stained cells to the total number of cells was calculated.

\section{Statistical analysis}

The results represent the data summarized from three experiments performed on separate days with distinct groups of granulosa cells that were obtained from 10-20 pigs. All the experimental groups were represented by three wells containing granulosa cells. The proportion of cells containing the specific immunoactivity were calculated from at least 1,000 cells per well, and the percentage of cells containing the antigens was determined after estimating the cell numbers. Significant differences between the experimental and control groups were evaluated with one- or two-way analysis of variance (ANOVA), followed by Duncan's test, using the software Sigma Plot 11.0 (Systat Software, GmbH, Erkrath, Germany); results were considered to be statistically significant at $\mathrm{P}<0.05$.

\section{Results}

Cultured porcine ovarian cells contained both PCNA and bax. PCNA was located primarily in the nuclei, and, to a lesser extent, in the cytoplasm, while bax was predominantly located in the cytoplasm (Fig. 1).
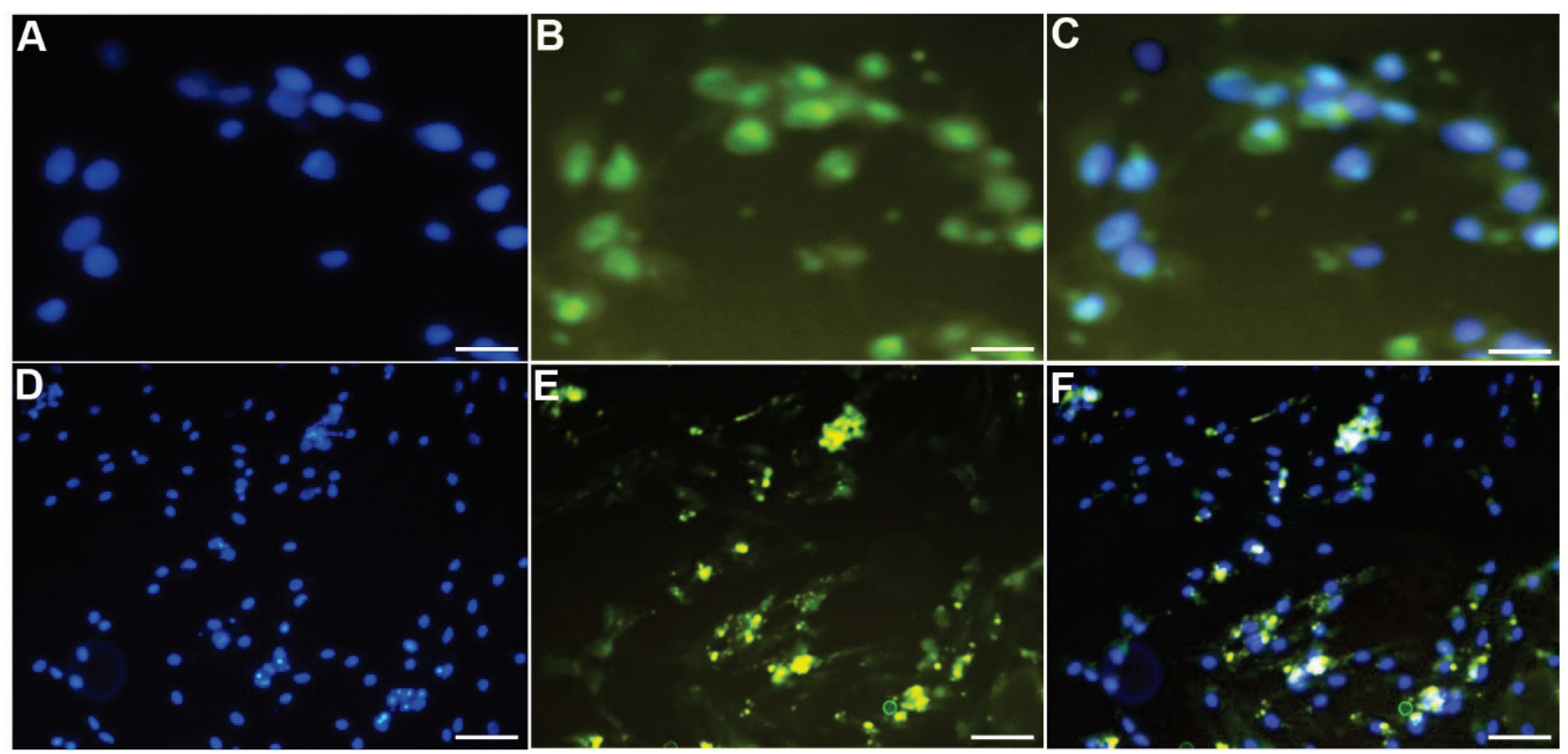

Fig. 1. Immunofluorescent detection of PCNA (A-C) and bax (D-F) proteins in porcine granulosa cells. Immunofluorescence was performed using specific PCNA and BAX primary antibodies. The Secondary antibody was labelled with FITC (green), cell nuclei were stained with DAPI (blue). Scale bar $=20 \mu \mathrm{m}$.
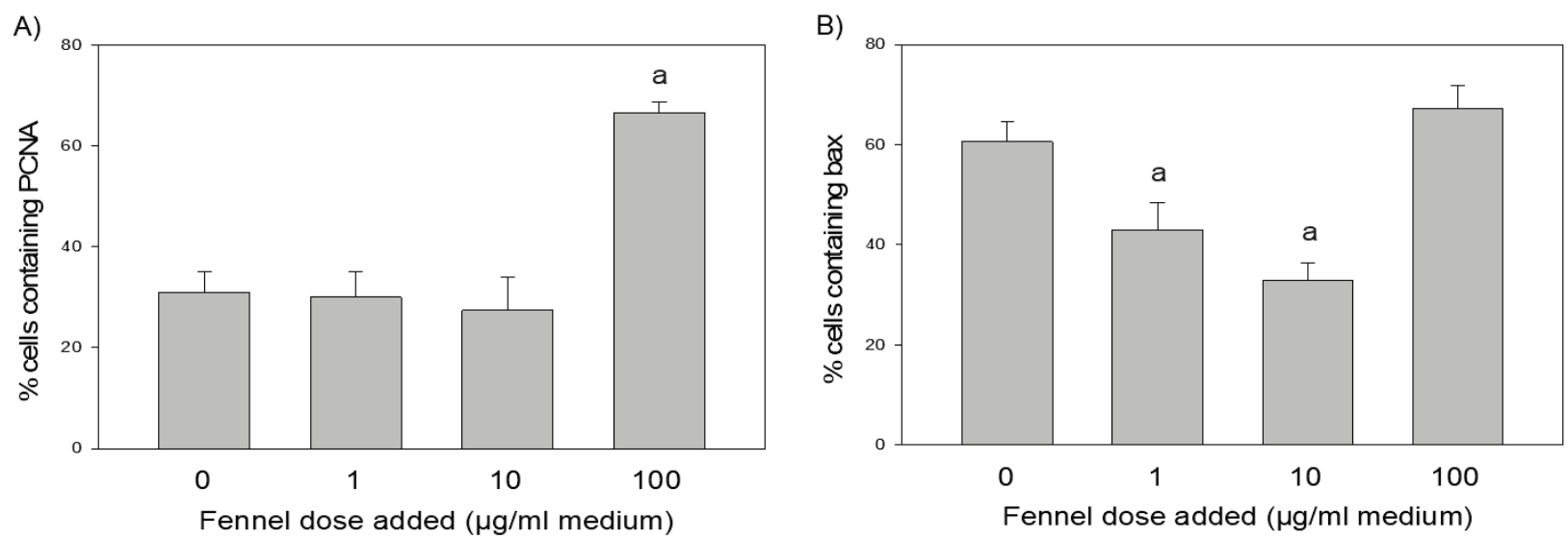

Fig. 2. The effect of the addition of fennel (Foeniculum vulgare Mill.) extract at concentrations of 0 (control), 1, 10, and $100 \mu \mathrm{g} / \mathrm{ml}$, on the expression of the proliferation marker PCNA (A) and the apoptosis marker Bax (B) in cultured porcine ovarian granulosa cells. Data were derived from quantitative immunocytochemical analysis. a: significant differences $(P<0.05)$ were observed between cells cultured with and without $(0 \mu \mathrm{g} / \mathrm{ml})$ fennel extract. 

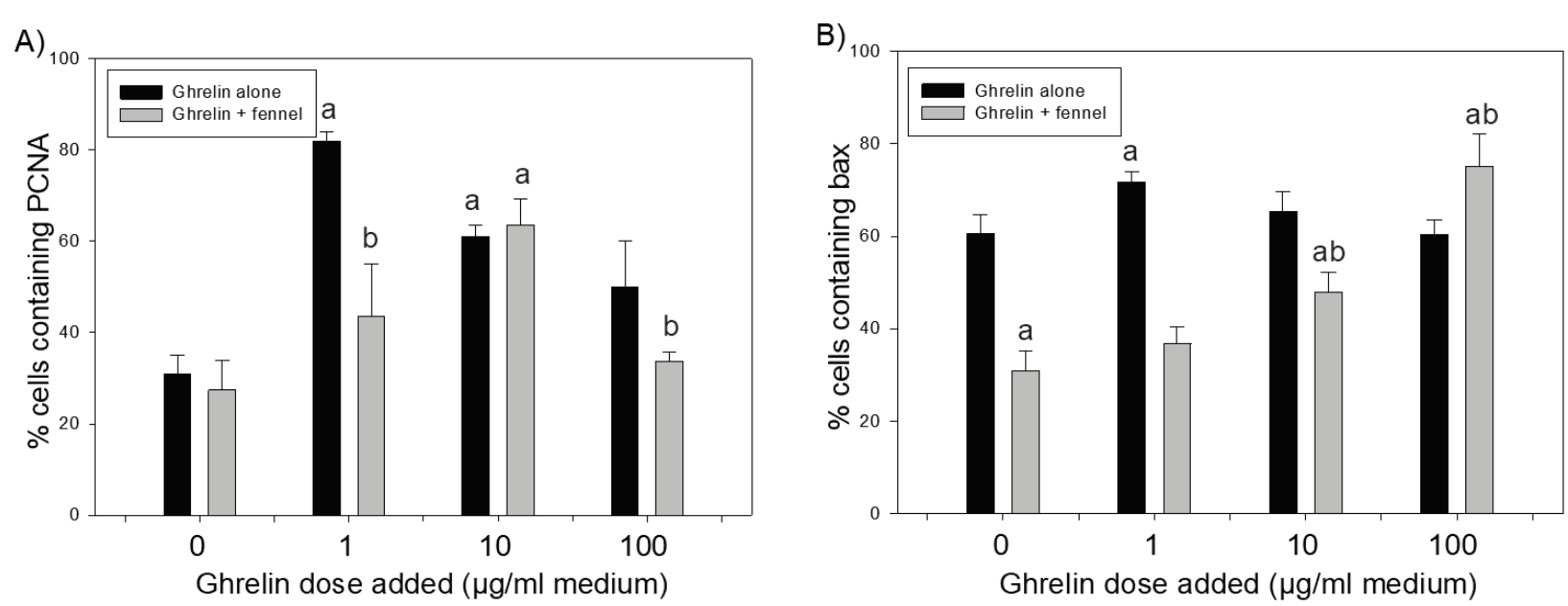

Fig. 3. The effect of the addition of ghrelin, at concentrations of 0 (control), 1,10 and $100 \mathrm{ng} / \mathrm{ml}$, either alone or in combination with $10 \mu \mathrm{g} / \mathrm{ml}$ fennel (Foeniculum vulgare Mill.) extract on the expression of the proliferation marker PCNA (A) and the apoptosis marker bax (B) in cultured porcine ovarian granulosa cells. Data were derived from quantitative immunocytochemical analysis. a: effect of fennel: significant differences $(P<0.05)$ were observed between the corresponding groups of cells cultured with and without fennel. b: effect of ghrelin: significant differences $(P<0.05)$ were observed between cells cultured with and without ghrelin.

The first series of experiments demonstrated that the addition of the fennel extract increased the percentage of cells containing PCNA (after addition at dose of $100 \mu \mathrm{g} / \mathrm{ml}$, Fig. 2A). Furthermore, addition of fennel extract (at doses of 1 or $10 \mu \mathrm{g} / \mathrm{ml}$ ) reduced the percentage of apoptotic (bax-positive) cells (Fig. 2B).

In the second series of experiments, similar to the first series, fennel, when added alone at dose $10 \mu \mathrm{g} / \mathrm{ml}$ (i.e. a ghrelin dose of $0 \mu \mathrm{g} / \mathrm{ml}$ ) did not affect the percentage of proliferating (PCNA-positive) cells (Fig. 3A), but reduced the percentage of apoptotic (bax-positive) cells (Fig. 3B).

In these experiments, ghrelin, when added alone, increased the proportion of PCNA-positive cells at all doses (Fig. 3A), and ghrelin increased the proportion of bax-positive cells at a dose of $1 \mathrm{ng} / \mathrm{ml}$. In presence of fennel, ghrelin (at a dose of $10 \mu \mathrm{g} / \mathrm{ml}$ ) promoted PCNA accumulation (Fig. 3A), and ghrelin promoted bax accumulation at the doses 10 and $100 \mu \mathrm{g} / \mathrm{ml}$ (Fig. 3B).

\section{Discussion}

Trypan blue staining and cell counting did not reveal differences in the number and viability of cells among the different groups of cells after two days of treatment (see Materials and Methods). Nevertheless, the presence of both PCNA (a marker of the S-phase of the cell cycle, (Shiomi and Nishitani 2017) and bax (a marker of cytoplasmic apoptosis, (Pena-Blanco and Garcia-Saez 2018), was observed in the cultured cells, which indicates that the cells used in experiments were viable, and that both proliferation and apoptosis had taken place in these cells. Furthermore, the results demonstrate that the addition of both fennel and ghrelin affected these processes.

The ability of fennel to promote proliferation (PCNA accumulation) and to suppress apoptosis (bax accumulation) suggests than this plant can change ovarian cell proliferation:apoptosis ratios in favor of proliferation, and therefore to stimulate ovarian cell functions, and probably ovarian follicullogenesis. These observations represent the first evidence for the influence of fennel on reproduction in pigs, and indeed any farm animal species. Furthermore, our results are the first demonstration that fennel can affect ovaries directly, i.e. not via the upstream central nervous system (CNS). These observations are in agreement with previous studies on the ability of fennel to stimulate ovarian follicullogenesis and fertility in other species: human women: (Albert-Puleo 1980, Badgujar et al. 2014) quails: (Cabuk et al. 2014) mice: (Khazaei et al. 2011, Hassanpour et al. 2017) rats: (Abdel-Wahab et al. 2017). Furthermore, our results provide a description of possible mechanisms of the stimulatory action of fennel on reproduction, i.e., via promotion of ovarian cell proliferation, reduction in ovarian cell apoptosis, and increases in the proliferation:apoptosis ratio.

Another possible mechanism by which fennel affects ovarian cells could be the fennel-induced change in the response of the ovary to ghrelin, an upstream hormonal regulator. In our experiment, when cells were cultured with only ghrelin, it promoted both proliferation 
and apoptosis. Increases in both these processes suggest that ghrelin could promote ovarian cell turnover, which defines the growth, development, selection, and finally the fecundity of ovarian follicles (Sirotkin 2014). This confirms the results of previous reports regarding the importance of this hormone in the direct control of basic ovarian functions in pigs and other species (Sirotkin and Meszarosova 2010, Sirotkin et al. 2011, Rak-Mardyla 2013, Sirotkin 2014, Fontana et al. 2020). Furthermore, in the present study, fennel suppressed ghrelin action on both proliferation and apoptosis - in the presence of fennel, the effective doses of ghrelin were significantly higher than in the absence of fennel. The ability of fennel to inhibit the response of ovarian cells to some exogenous drugs that suppress reproduction has been previously reported. Fennel has been found to increase the response of mouse ovaries to cyclophosphamide (Hassanpour et al. 2017) and the response of rat ovaries to cadmium (AbdelWahab et al. 2017). To the best of our knowledge, the present study is the first to demonstrate the ability of fennel to reduce ovarian responses to an upstream hormonal stimulator.

The mechanisms of fennel action on all these processes require further elucidation. Nevertheless, previous studies indicate that the reproduction-promoting effect of fennel could be due to the presence of phytoestrogens (Rahimi and Ardekani 2013, Badgujar et al. 2014, Sadati et al. 2016). Plant and animal estrogens can induce various reproductive and nonreproductive processes (Sirotkin and Harrath 2014), including promotion of ovarian cell proliferation, inhibition of ovarian cell apoptosis, and plant and animal estrogens can affect hormonal reception and response to upstream hormonal regulators (Sirotkin 2014, Sirotkin et al. 2020). In addition, fennel can inhibit the nuclear transcription factor-kappaB pathway involved in the control of a wide array of physiological processes (Aggarwal and Shishodia 2004), including porcine ovarian cell proliferation and apoptosis (Pavlova et al. 2011, Pavlova et al. 2013, Sirotkin et al. 2014).

The results of the present study also suggest the potential applicability of fennel in animal production, not only as an anti-bacterial and digestion-promoting food additive (Patra et al. 2010, Abdalla et al. 2012, Cabuk et al. 2014, Dragan et al. 2014, Saeedi et al. 2017), but also as a potential stimulator of reproduction. To validate this hypothesis, in-vivo experiments in farm animals are needed.

Although the mechanisms and areas of application of fennel require further elucidation, our observations provide the first demonstration of (1) effects of fennel on farm animal reproduction, (2) direct effects of fennel on ovarian cells, (3) the ability of fennel to promote ovarian cell proliferation, to inhibit ovarian cell apoptosis, and to increase the ovarian cell proliferation:apoptosis ratio. Furthermore, our results (4) confirm the involvement of ghrelin in control of ovarian cell apoptosis and proliferation, and (5) demonstrate the ability of fennel to affect not only ovarian cell proliferation and apoptosis, but also to suppress the responses of ovarian cells to the upstream hormonal regulator, ghrelin. Our results indicate the potential applicability of fennel as a bio-stimulator of farm animal reproduction.

\section{Conflict of Interest}

There is no conflict of interest.

\section{Ethics statement}

This research did not include any human subjects and animal experiments.

\section{Acknowledgements}

The authors express their gratitude to Ing. Ž. Kuklová and Mrs. K. Tóthová for their skillful technical assistance, as well as to Dr. A. Makarevich for kind help in fluorescent microscopy. These studies were supported by the Slovak Research and Development Agency (APVV) under the contract APVV-15-0296, the Slovak Grant Agency of the Ministry of Education, Science and Sport, the Slovak Academy of Science (VEGA) projects (VEGA 1/0392/17) and the Researchers Supporting Project number RSP-2021/17, King Saud University, Riyadh, Saudi Arabia.

\section{References}

ABDALLA AL, LOUVANDINI H, SALLAM SM, BUENO IC, TSAI SM, FIGUEIRA AV: In vitro evaluation, in vivo quantification, and microbial diversity studies of nutritional strategies for reducing enteric methane production. Trop Anim Health Prod 44: 953-964, 2012. https://doi.org/10.1007/s11250-011-9992-0 
ABDEL-WAHAB A, HASHEM ABDEL-RAZIK AR, ABDEL AZIZ RL: Rescue effects of aqueous seed extracts of Foeniculum vulgare and Carum carvi against cadmium-induced hepatic, renal and gonadal damage in female albino rats. Asian Pac J Trop Med 10: 1123-1133, 2017. https://doi.org/10.1016/j.apjtm.2017.10.019

AGGARWAL BB, SHISHODIA S: Suppression of the nuclear factor-kappaB activation pathway by spice-derived phytochemicals: reasoning for seasoning. Ann N Y Acad Sci 1030: 434-441, 2004. https://doi.org/10.1196/annals.1329.054

ALBERT-PULEO, M: Fennel and anise as estrogenic agents. J Ethnopharmacol 2(4): 337-344, 1980. https://doi.org/10.1016/S0378-8741(80)81015-4

BADGUJAR SB, PATEL VV, BANDIVDEKAR AH: Foeniculum vulgare Mill: a review of its botany, phytochemistry, pharmacology, contemporary application, and toxicology. Biomed Res Int 2014: 842674, 2014. https://doi.org/10.1155/2014/842674

CABUK M, ERATAK S, ALCICEK A, BOZKURT M: Effects of herbal essential oil mixture as a dietary supplement on egg production in quail. Sci World J 2014: 573470, 2014. https://doi.org/10.1155/2014/573470

CIRMANOVA V, ZOFKOVA I, KASALICKY P, LANSKA V, BAYER M, STARKA L, KANCEVA R: Hormonal and bone parameters in pubertal girls. Physiol Res 66 (Suppl 3): S419-S424, 2017. https://doi.org/10.33549/physiolres. 933733

DRAGAN L, GYORKE A, FERREIRA JF, POP IA, DUNCA I, DRAGAN M, MIRCEAN V, DAN I, COZMA V: Effects of Artemisia annua and Foeniculum vulgare on chickens highly infected with Eimeria tenella (phylum Apicomplexa). Acta Vet Scand 56: 22, 2014. https://doi.org/10.1186/1751-0147-56-22

FONTANA J, MARTINKOVA S, PETR J, ZALMANOVA T, TRNKA J: Metabolic cooperation in the ovarian follicle. Physiol Res 69: 33-48, 2020. https://doi.org/10.33549/physiolres.934233

HASSANPOUR A, YOUSEFIAN S, ASKARIPOUR M, SHARIFIFAR F, EZZATABADIPOUR M: Ovarian protection in cyclophosphamide-treated mice by fennel. Toxicol Rep 4: 160-164, 2017. https://doi.org/10.1016/j.toxrep.2017.03.002

KHAZAEI M, MONTASERI A, KHAZAEI MR, KHANAHMADI M: Study of Foeniculum vulgare Effect on Folliculogenesis in Female Mice. Int J Fertil Steril 5: 122-127, 2011.

PATRA AK, KAMRA DN, AGARWAL N: Effects of extracts of spices on rumen methanogenesis, enzyme activities and fermentation of feeds in vitro. J Sci Food Agric 90: 511-520, 2010. https://doi.org/10.1002/jsfa.3849

PAVLOVA S, KLUCSKA K, VASICEK D, KOTWICA J, SIROTKIN AV: Transcription factor NF-kappaB (p50/p50, p65/p65) controls porcine ovarian cells functions. Anim Reprod Sci 128: 73-84, 2011. https://doi.org/10.1016/j.anireprosci.2011.09.005

PAVLOVA S, KLUCSKA K, VASICEK D, RYBAN L, HARRATH AH, ALWASEL SH, SIROTKIN AV: The involvement of SIRT1 and transcription factor NF-kappaB (p50/p65) in regulation of porcine ovarian cell function. Anim Reprod Sci 140: 180-188, 2013. https://doi.org/10.1016/j.anireprosci.2013.06.013

PENA-BLANCO, A, GARCIA-SAEZ, AJ: Bax, Bak and beyond - mitochondrial performance in apoptosis. FEBS J 285: 416-431, 2018. https://doi.org/10.1111/febs.14186

RAHIMI, R, ARDEKANI, MR: Medicinal properties of Foeniculum vulgare Mill. in traditional Iranian medicine and modern phytotherapy. Chin J Integr Med 19: 73-79, 2013. https://doi.org/10.1007/s11655-013-1327-0

RAK-MARDYLA A: Ghrelin role in hypothalamus-pituitary-ovarian axis. J Physiol Pharmacol 64: 695-704, 2013.

SADATI SN, ARDEKANI MR, EBADI N, YAKHCHALI M, DANA AR, MASOOMI F, KHANAVI M, RAMEZANY F: Review of scientific evidence of medicinal convoy plants in traditional persian medicine. Pharmacogn Rev 10: 33-38, 2016. https://doi.org/10.4103/0973-7847.176546

SAEEDI, S, DAYANI, O, TAHMASBI, R, KHEZRI, A: Effect of supplementation of calf starter with fennel powder on performance, weaning age and fermentation characteristics in Holstein dairy calves. J Anim Physiol Anim Nutr (Berl) 101: 81-87, 2017. https://doi.org/10.1111/jpn.12511

SHIOMI, Y, NISHITANI, H: Control of genome integrity by RFC complexes; Conductors of PCNA loading onto and unloading from chromatin during DNA replication. Genes (Basel) 8: 52, 2017. https://doi.org/10.3390/genes8020052

SIROTKIN AV: Regulators of ovarian functions. In: New York, USA: Nova Publishers. Inc; 2014, p. 194. 
SIROTKIN AV, DEKANOVA P, HARRATH AH: FSH, oxytocin and IGF-I regulate the expression of sirtuin 1 in porcine ovarian granulosa cells. Physiol Res 69: 461-466, 2020. https://doi.org/10.33549/physiolres.934424

SIROTKIN AV, DEKANOVA P, HARRATH AH, ALWASEL SH, VASICEK D: Interrelationships between sirtuin 1 and transcription factors $\mathrm{p} 53$ and NF-kappaB (p50/p65) in the control of ovarian cell apoptosis and proliferation. Cell Tissue Res 358: 627-632, 2014. https://doi.org/10.1007/s00441-014-1940-7

SIROTKIN AV, HARRATH AH: Phytoestrogens and their effects. Eur J Pharmacol 741: 230-236, 2014. https://doi.org/10.1016/j.ejphar.2014.07.057

SIROTKIN AV, MESZAROSOVA M: Comparison of effects of leptin and ghrelin on porcine ovarian granulosa cells. Domest Anim Endocrinol 39: 1-9, 2010. https://doi.org/10.1016/j.domaniend.2009.06.001

SIROTKIN AV, MESZAROSOVA M, GROSSMANN R, BENCO A, VALENZUELA F: Effect of inhibitor and activator of ghrelin receptor (GHS-R1a) on porcine ovarian granulosa cell functions. Gen Comp Endocrinol 173(1): 105-110, 2011. https://doi.org/10.1016/j.ygcen.2011.05.001 